\title{
Parental practices and beliefs on motor development in the first year of life
}

\author{
Práticas e crenças parentais relativas ao \\ desenvolvimento motor no primeiro ano de vida
}

\author{
Alcilene Maria Gomes ${ }^{[a]}$, Rayane Fonseca Ribeiro ${ }^{[a]}$, Bernat Vinolas Prat ${ }^{[a]}$, \\ Lívia de Castro Magalhães ${ }^{[\mathrm{b}]}$, Rosane Luzia de Souza Morais ${ }^{[]^{[}}{ }^{*}$ \\ [a] Universidade Federal dos Vales do Jequitinhonha e Mucuri (UFVJM), Diamantina, MG, Brazil \\ [b] Universidade Federal de Minas Gerais (UFMG), Belo Horizonte, MG, Brazil
}

\begin{abstract}
Introduction: In the child's first year of life, motor development is critical for the other areas of child development. Beliefs and parenting practices influence the parents' care and encouragement of their children, reflecting in their motor development; however, the Brazilian literature on this subject is scarce. Objective: to characterize the parental practices and beliefs associated with motor development in the first year of life; and to verify if practices and beliefs are interrelated. Methods: Two questionnaires were developed and applied, one about parenting practices and the other about parental beliefs on motor development in the first year life, to 27 caregivers of children between 12 and 24 months of age, who participated in an aquatic stimulation program. The agreement between practices and beliefs was verified by a graphical method, based on the transformation of ordinal scores to an interval scale using Rasch analysis. Results: The participants had higher levels of education and economic status. They reported a variety of practices focused on the motor development of their children, such as family interaction through playing, toy offers, lap time and free movement space. Conclusion: Most of the practices were based on parental beliefs, for some activities, however, beliefs and practices diverged, demonstrating the complexity inherent to the formation of parental beliefs.
\end{abstract}

Keywords: Child Development. Parent-Child Relationships. Cultural Characteristics.

\footnotetext{
AMG: Master Student, e-mail: alcilene-gomes@hotmail.com

RFR: undergrad, e-mail: raay12ribeiro@gmail.com

BVP: PhD, e-mail: bernatvinolasprat@gmail.com

LCM: PhD, e-mail: liviacmag@gmail.com

RLSM: PhD, e-mail: rosanesmorais@gmail.com
} 
Resumo

Introdução: O desenvolvimento motor, no primeiro ano de vida, é fundamental para os demais domínios do desenvolvimento infantil. Crenças e práticas parentais implicam no cuidado e estímulos dos pais com suas crianças refletindo no desenvolvimento motor, porém, a literatura brasileira sobre esta temática é escassa. objetivo: Caracterizar as práticas e crenças parentais relacionadas ao desenvolvimento motor no primeiro ano de vida; e verificar se as práticas e as crenças estão relacionadas entre si. Métodos: Foram elaborados e aplicados dois questionários, um sobre práticas e outro sobre crenças parentais no desenvolvimento motor em 27 cuidadores de crianças com idade entre 12 e 24 meses participantes de um programa de estimulação aquática. A concordância entre práticas e crenças foi verificada por um método gráfico a partir da transformação dos escores ordinais em escala intervalar pela análise Rasch. Resultados: Os participantes deste estudo tinham níveis de escolaridade e econômico mais elevados e apresentavam práticas variadas voltadas para o desenvolvimento motor de suas crianças tais como: a interação familiar por meio de brincadeiras, oferta de brinquedos, colo e espaço para liberdade de movimento. Conclusão: As práticas estiveram em sua maioria baseadas em crenças parentais, no entanto, para algumas atividades, crenças e práticas divergiram refletindo a complexidade inerente à formação das crenças parentais.

Palavras-chave: Desenvolvimento Infantil. Relações Pais-Filho. Características Culturais.

\section{Introduction}

Childhood development is defined by the ordered development of skills in different domains: motor, cognitive and affective-social, depending on the child's physical wellbeing, the family context and an extensive social network (1).

The family environment plays a fundamental role in the child's development. The parents are responsible for attending to basic needs, such as affection, feedings, suitable hygiene and health conditions, safety, besides promoting an environment that stimulates childhood development $(2,3)$. In addition, the parents transmit cultural and educational values to the children that support the demands for social adaptation $(1,4)$. Therefore, from birth, the children are inserted in culturally organized environments and the adults receive them with beliefs, expectations, representations and practices mediated by the instruments of that culture (4).

According to Harkness and Super (5), beliefs can be defined as a set of ideas that are related to the daily activities, referring to the judgments and choices the parents make, as if they were scripts to guide their actions. The relations the parents establish with their children are based on the need to take care, educate and promote the children's development, constituting a characteristic set of behaviors that can be defined as parental practices (6).

Therefore, deepening the knowledge on this theme is relevant for the professionals who work with children, as these practices and beliefs affect the care and stimuli the parents offer to the children, influencing their childhood development (4). Understanding these beliefs and parental practices related to the motor behavior in the first year of life is fundamental, considering that, in this phase, the motor development directly influences the other domains of childhood development (7-9).

The influence of socioeconomic indicators on the motor development within the family environment $(10-12)$ has been widely studied, but little has been investigated on the parenting practices and beliefs in this specific domain of childhood development. In the Brazilian literature, only two studies were found in this area. Silva et al. (13) analyzed the influence of some parenting practices on the motor development and Chagas et al. (14) verified the parental beliefs on the use of walkers in the motor development. Thus, the objective in this study was to characterize the parenting practices and beliefs related to motor development in the first year of life. A second objective was to verify if the practices and beliefs are mutually related. Based on the results found, it 
can be verified whether the parents promote opportunities for the motor development to emerge.

\section{Methods}

Type of study and participants

Cross-sectional, descriptive and observational study, approved by the Research Ethics Committee at Universidade Federal dos Vales do Jequitinhonha e Mucuri (UFVJM), developed at the university headquarters located in a city in Minas Gerais. A convenience sample was recruited. To participate, the primary caregivers - the person responsible for direct and daily care, in most cases the mother (15) - of children between 12 and 24 months who were duly registered in the child aquatic stimulation project "Nada Melhor" (which means "swim better" or/and "there is nothing better") were invited. This community service project is undertaken at the Physiotherapy Department of UFVJM to offer neuropsychomotor stimulation through aquatic activities, once per week, during 50 minutes, for children from the community.

\section{Instruments}

For the economic classification of the families, the Brazilian Economic Classification Criterion (CCEB) of the Brazilian Association of Research Companies was used (16). The CCEB is a questionnaire in which the economic classification is basically defined according to the durable goods at the home and the family head's instruction level. The item scores are added up and interpreted by means of a table, ranging from E to $A_{1}(16)$.

To characterize the study sample, a questionnaire was elaborated to collect data on the families' sociodemographic conditions and the participating children's biological profile. The primary caregiver was requested to answer the questionnaire.

Two structured questionnaires were applied, specifically elaborated for this study based on existing information in the literature about practices that can interfere in child motor development, such as: where the child is placed when awake (floor, cradle, stroller, walker, lap); the position in which the child is left when on the floor (sitting, in prone position, in dorsal position, standing); use of equipment (carrying basket, baby bouncer, high chair, playpen) and stimulation material (for example toys, books, etc.) $(11-14,17,18)$. The first questionnaire consisted of 30 questions about practices performed in the first year of life and the alternative answers were provided on a five-point Likert scale: 01-never, 02-rarely, 03-sometimes, 04-almost always and 05 -always. The second questionnaire contained the same questions as the first, but the caregiver was asked to rate the importance of each practice in the child's motor development and the alternative answers were: 01-not at all, 02-a little, 03-more or less, 04-a lot and 5-very much. The latter questionnaire reflected the parental beliefs on the stimuli and care related to the motor development in the first year of life. In addition, for the two questionnaires, the caregivers were asked to describe the type of toys, games and equipment used.

\section{Procedures}

The participating children's caregivers were contacted during the sessions of the aquatic stimulation project. The researcher applied the questionnaires while the caregiver was waiting for his/her child to participate in the aquatic stimulation. In some cases, the data were collected at home as requested by the child's caregiver.

\section{Data analysis statistics}

To organize the data, the statistical software Microsoft Excel version 2010 was used for descriptive analysis, characterization of the participants and construction of the questionnaire graphs. To check the agreement between the questionnaire answers, the Rasch analysis software Winsteps 3.91.2 was used to transform the original ordinal scores into interval scales. Rasch is the name of a logistic transformation model that is frequently used to create interval scales in rehabilitation (19). Through transformations based on the principle that more skilled people score higher and respond better to motor difficult items than less skilled people, the program calibrates the items from easier to more difficult, building a linear continuum of skills that serves as a ruler to measure people's skill. The interval measuring units are called logits, which can 
be negative or positive (19). Each item presents an error margin that indicates the reliability of the measure. The higher the logit of a certain item, the greater the item's difficulty or, in the questionnaires studied, the lower the score in practices and in the importance of that activity for the caregivers when compared to other items. The greater the measuring error, the less trust in the acuity of the measure.

The two questionnaires - parental practices and importance of parental practices - were analyzed independently, obtaining the calibration in logit (difficulty level) for each questionnaire item. Differences between the logits of the corresponding items in the two questionnaires were analyzed by means of a graphical method $(20,21)$ used in other studies $(22,23)$. In a graph, the calibration of the practice questionnaire items was represented in logits in comparison with the calibration of the importance questionnaire items, outlining quality control lines by means of the errors associated with the estimation of each calibration $( \pm 2 \mathrm{E}=95 \%$ confidence interval). As the mean calibration of the items in both questionnaires is centered in zero, the relation between the two calibrations should be statistically linear, with most items being located between the quality control lines. When more than $5 \%$ of the items are located beyond the quality control lines, this means that the calibration of the items in the two questionnaires differs.

\section{Results}

\section{Participants' characteristics}

The study participants were the 27 caregivers of all children between 12 and 24 months of age, as none of them refused. Seventeen children were female and nine attended kindergartens, all privately held. Twenty-six children manifested typical development characteristics and only one child had been diagnosed with cerebral palsy. As the results of this child's questionnaire did not differ from the others, we decided to keep her in the study. In most cases, the caregiver who answered the questionnaires was the mother (Table 1).

Table 1 presents the families' sociodemographic characteristics. The majority had both parents and belonged to medium or high economic levels. Both the fathers and mothers were in the adult age range and presented higher education levels. Most children had no siblings.

Table 1 - Sociodemographic characteristics, DiamantinaMG, 2016.

\begin{tabular}{|c|c|c|}
\hline Characteristics & & N (\%) \\
\hline \multicolumn{3}{|l|}{ Who answered } \\
\hline $\begin{array}{l}\text { Mother } \\
\text { Father } \\
\text { Others* }\end{array}$ & & $\begin{array}{c}19(70.4) \\
5(18.5) \\
3(11.1)\end{array}$ \\
\hline \multicolumn{3}{|l|}{ Mothers } \\
\hline Mother's age & $\begin{array}{l}\text { Younger than } 20 \text { years } \\
20 \text { years or older }\end{array}$ & $\begin{array}{c}0(0.0) \\
27(100)\end{array}$ \\
\hline $\begin{array}{l}\text { Education } \\
(\mathrm{n}=27)\end{array}$ & $\begin{array}{l}\text { Illiterate/unfinished primary } \\
\text { Finished primary/up to } 4^{\text {th }} \text { grade } \\
\text { Finished primary } \\
\text { Finished secondary } \\
\text { Finished higher } \\
\text { Finished post-graduate }\end{array}$ & $\begin{aligned} 0 & (0.0) \\
0 & (0.0) \\
1 & (3.7) \\
10 & (37.0) \\
14 & (51.9) \\
& 2(7.4)\end{aligned}$ \\
\hline \multicolumn{3}{|l|}{ Fathers } \\
\hline Father's age & $\begin{array}{l}\text { Younger than } 20 \text { years } \\
20 \text { years or older }\end{array}$ & $\begin{array}{c}0(0.0) \\
27(100)\end{array}$ \\
\hline $\begin{array}{l}\text { Education } \\
(n=27)\end{array}$ & $\begin{array}{l}\text { Illiterate/unfinished primary } \\
\text { Finished primary/up to } 4^{\text {th }} \text { grade } \\
\text { Finished primary } \\
\text { Finished secondary } \\
\text { Finished higher } \\
\text { Finished post-graduate }\end{array}$ & $\begin{array}{c}0(0.0) \\
0(0.0) \\
4(14.8) \\
8(29.6) \\
12(44.4) \\
3(11.1)\end{array}$ \\
\hline \multicolumn{3}{|l|}{ Families ( $n=27$ ) } \\
\hline \multirow[t]{4}{*}{ Type } & Single female parent & $2(7.4)$ \\
\hline & Expanded single-parent ${ }^{1}$ & $4(14.8)$ \\
\hline & Two-parent & $18(66.7)$ \\
\hline & Expanded two-parent ${ }^{2}$ & $3(11.1)$ \\
\hline Economic level & $\begin{array}{l}\text { Class A2 } \\
\text { Class B1 } \\
\text { Class B2 } \\
\text { Class C1 }\end{array}$ & $\begin{array}{l}6(22.2) \\
9(33.3) \\
7(25.9) \\
5(18.5)\end{array}$ \\
\hline \multirow{3}{*}{$\begin{array}{l}\text { Number of } \\
\text { siblings }\end{array}$} & None & $16(59.3)$ \\
\hline & One & $5(18.5)$ \\
\hline & Others & $6(22.2)$ \\
\hline
\end{tabular}

Note: ${ }^{1}$ Extended single-parent: mother, children and other relatives;

2 Expanded two-parent: couple, children and other relatives;

* One aunt and two nannies.

\section{Parenting practices}

Figure 1 displays the results of the parenting practices questionnaire in the first year of life. It was verified that the most frequent practices over time were "playing" or "giving toys" to the child. 
The caregivers were asked what toys they offered and what games they played. Up to the age of three months, the most offered toys were rattles and teething rings (74\%), followed by balls, bath books, silicone forms and mobiles (18.5\%). Some mentioned that they could not recall the toy offered or answered that they did not offer toys (7.4\%). Between four and six months, $37 \%$ of the caregivers also offered the rattle or teething rings, followed by balls (18.5\%), plush animals or dolls (22.2\%), miniature cars (11.1\%), mobiles (3.7\%) and some reported that they could not recall the toy offered $(7.4 \%)$. As from the age of six months, the most offered toys were the ball (22.2\%) and the rattle (22.2\%), followed by music instruments $(11.1 \%)$, dolls or miniature cars (18.5\%), slotting toys and blocks (14.8\%), play telephones (3.7\%), mobiles $(3.7 \%)$, while some caregivers could not recall what toy they offered to the child (3.7\%).
Concerning the games, between zero and three months, all caregivers smiled and made faces; between four and six months, the most frequent game was "hide and seek" (33.3\%), followed by "singing and clapping" (25.9\%), tickling or massage (11.1\%). Some interviewees said they had not played any specific game or could not recall the game $(29.4 \%)$. As from the age of six months, "hide and seek" (25.9\%) was the most frequent game, followed by singing (18.5\%), playing with the ball (11.1\%), running, dancing or playing in a ring (14.8\%). In addition, drawing, reading books, playing with the child's toys and pedagogical toys (14.8\%) were mentioned, while some (14.8\%) mentioned they did not recall the games they had played.

Other practices continued hardly frequent in the first year of life, such as "leaving the infant in the cradle" or "leaving the infant in the stroller". The use of other equipment was not very frequent either and dropped with age (Figure 1).

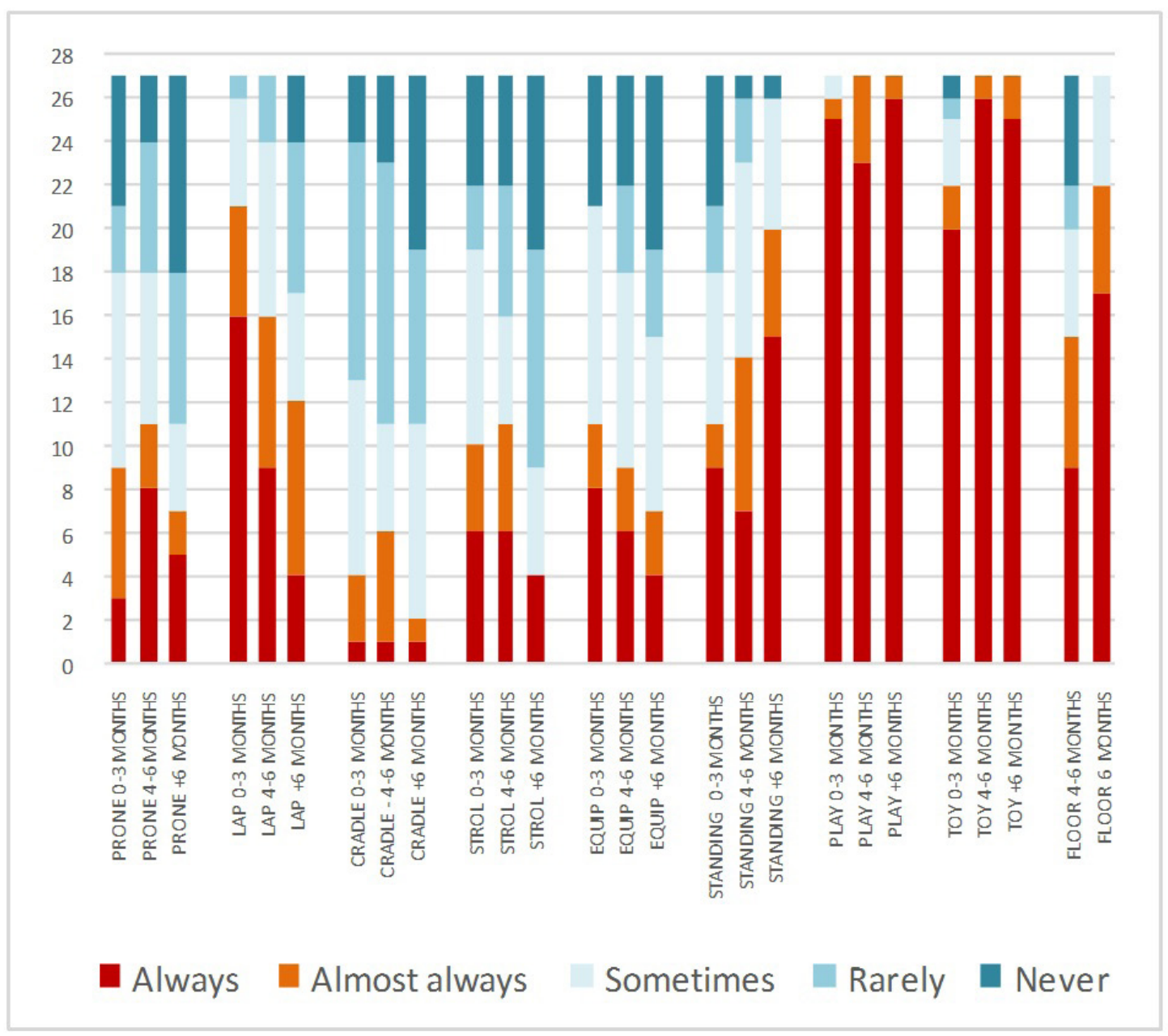

Figure $\mathbf{l}$ - Number of answers to the questionnaire - Parenting practices. Note: PRON: prone; STROL: Stroller; EQUIP: Equipment; TOY: Toys. 
When considering the caregivers who reported using equipment, in the first three months, the three most mentioned types of equipment were the carrying basket (63\%), followed by the playpen $(7.4 \%)$ and the bouncer (3.7\%). Between four and six months of age, the caregivers indicated that the playpen was the most use piece of equipment (33.3\%), followed by the carrying basket (37\%) and the bouncer (7.4\%). As from the age of six months, the playpen became more frequent (51.9\%), 11.1\% used the carrying basket the most frequently and $3.7 \%$ mentioned other equipment, such as the high chair and a toy motorcycle.

On the other hand, "lap" was one of the most frequent practices along the first year of life, although it dropped along the different age ranges (Figure 1). Some practices became more common during the first year of life, such as leaving on the floor and standing with support. As from the age of four months, although more than $50 \%$ of the caregivers mentioned "leaving the infant on the floor", leaving the infant on the floor in the dorsal or prone position were less usual, while the caregivers most frequently chose the sitting position.
"Putting the infant in the standing position" is an increasing practice with age (Figure 1). It is highlighted that about $41 \%$ of the fathers usually put their children in that position since the first term of life. The prone position was one of the least frequent parenting practices. Between four and six months of age was the age range that most practiced this position, that is, $40 \%$ of the mothers "almost always" or "always" put the child in the prone position. According to the mothers' reports, the three most mentioned locations to put the child in this position were on the bed (44.4\%), followed by the cradle $(25.9 \%)$ and the floor $(14.8 \%)$.

\section{Beliefs on parenting practices}

Figure 2 presents the results of the questionnaire on the importance of parenting practices. It was observed that, between zero and three months of age, the items the caregivers considered the most important were "playing with the child", followed by "giving toys" and "taking the child on the lap".

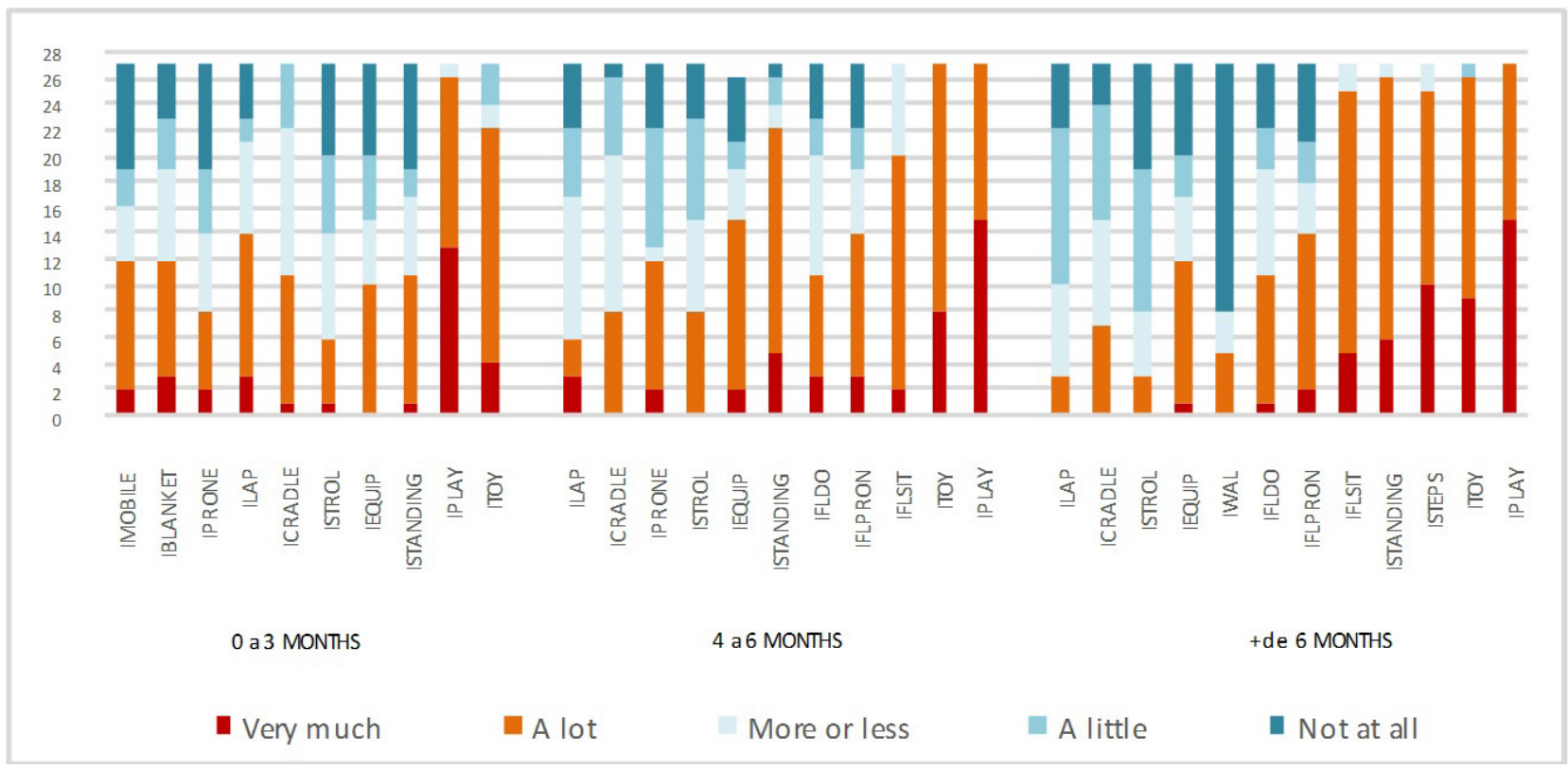

Figure 2 - Number of answers to the questionnaire - parental beliefs.

Note: I: importance; STROL: Stroller; EQUIP: Equipment; TOY: Whether the caregivers gave toys; FLDO: On the floor in dorsal; FLPRON: On the floor in prone; FLSIT: On the floor sitting; WAL: walker. 
In the first term, putting the infant in the "stroller", in the "prone" position and in "some equipment" were the least important practices. Between four and six months and after six months, the most important practices were "giving toys", "playing with the child" and "putting the child in the standing position". The least important practices for this period were "lap", "cradle" and "stroller". After the age of six months, however, the "use of the walker" stood out, which more than $70 \%$ of the caregivers considered "not at all" important.

\section{Comparison between Parenting Practices and Beliefs in Motor Development}

Figure 3 shows that, among the 33 items analyzed, nine are located beyond the control lines drawn in the graph, which means that their logit values differed in the two continua. Nine items presented calibration differences between the two questionnaires, four items were located superior to the lines, indicating greater difficulty to agree with the importance of the parental practices: "leaving on the lap" between four and six months and over six months of age, using the "stroller" and the "walker" over six months of age. In the other five items with significant calibration differences, the parents faced greater difficulties to report parenting practices when compared to the importance they attribute to these practices: "take steps" over six months of age, "stay on the floor sitting" between four and six months, "leaving the child in the cradle" between zero and three months, "leaving the child in the dorsal position on the floor" between four and six months and between six months and one year.

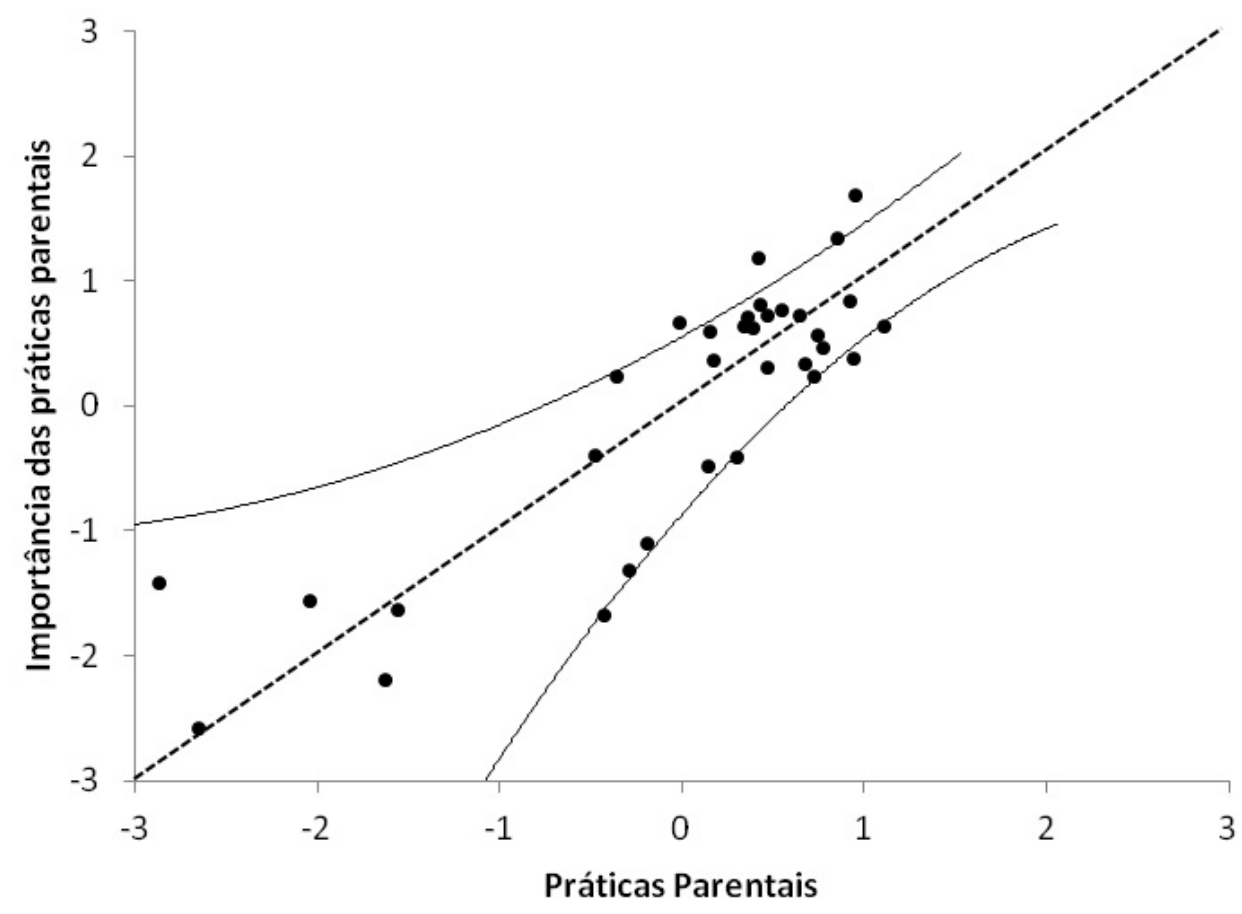

Figure 3 - Comparison between calibration of items in the parenting practices questionnaire and the importance of parenting practices questionnaire in motor development.

Note: The sense of the difference is illustrated by the location of the items beyond the quality control lines. The items located above and beyond the quality control lines drawn in the graph $(n=9)$ presented a significant difference in the logit received in both questionnaires. Four items presented relatively higher levels of difficulty (lower score) for the importance of parenting practices (superior to upper control line) and five items obtained relatively higher levels for parenting practices (inferior to lower control line). The items located inside the quality control lines $(n=24)$ obtained similar calibrations (logit) in the two questionnaires. 


\section{Discussion}

The quality of the home environment is very important for the child development. This varies with the parents' supply of care and attention, as well as with the parenting practices and beliefs $(2-4,12)$. In this study, overall, we observed that the parents presented different practices based on their beliefs and offered different toys and games in the course of the age ranges studied. As this group participated in an aquatic stimulation program, these parents valued their children's moment of stimulation or leisure. Therefore, these parents probably promote opportunities to stimulate their children in other environments (24).

In addition, it was verified that the children and their families who participated in this research presented sociodemographic and economic characteristics compatible with higher socioeconomic classes. According to the literature, indicators like higher education and socioeconomic level predict the promotion of an environment that is more favorable to child development $(10-12,25)$.

According to Defilipo et al. (10), the mothers with a higher instruction level, higher income, greater access to information and better knowledge on the development process of their children can positively contribute to the stimulation opportunities available at their homes. In a study by Martins et al. (26) involving 606 mothers, 307 of whom lived in small cities and 299 in six state capitals, it was identified that the educational level affects both the stimulation frequency and its valuation. The higher the mothers' education level, the more they affirmed stimulation care and the higher they valued this care.

In this study, playing with the child and giving toys were the most frequent and the highest valued practices along the first year of life. Giving toys and playing are some of the action possibilities offered in the environment the individual is inserted in which, through experience, exploration and perception (12), favor the motor development.

Carrying the child on the lap also stood out across all age ranges, while leaving the child awake in the cradle was a hardly frequent activity and belief. Karasik et al. (17) observed five-month-old infants and their mothers in six different cultures at their homes for one hour while engaged in common daily activities. The authors found no mutual differences in the time they spent with the infants on the lap, as all of them kept their infants on the lap for about one third of the time.

In this study, after the age of six months, putting the child on the floor was an activity most caregivers practiced. In a longitudinal study, Silva et al. (13) verified whether parenting practices related to the form of carrying, place and position influenced the gross motor development of 14 infants in the first year of life born in the interior of the state of São Paulo. These authors affirm that, as from the age of six months, the practice of putting the child on the floor positively influenced his/her motor performance as it grants greater freedom of movement.

Despite the different practices, in this study, it was observed that the mothers hardly explored some practices favorable to the motor development $(13,18)$, such as putting the infant in the prone position throughout the first year of life. Even when the caregivers put the child on the floor, the preferred position was sitting. Similar results were found in other studies that affirm that this practice is hardly frequent among Brazilian mothers $(13,27)$.

It is interesting to observe that the participating caregivers valued and practiced positions like sitting, walking and stimulating steps. This stimulation varies across different cultures (4). Canadian and American children are put more in the prone position than Brazilian infants $(13,27)$. These differences also happen in different Brazilian regions. Bezerra et al. (28) studied the influence of the secular practice of putting the infant to sleep in a hammock on the motor development in some regions of the Brazilian Northeast.

Differently from the study by Silva et al (13), the stroller was not much used. The use of the stroller may have been hardly frequent due to the irregular topography and historical architecture of the city under analysis, consisting of considerable slopes and stone pavements in many streets, making it difficult to use the strollers. According to Bezerra et al. (28), the environment the infant lives in can grant different formats or mold aspects of his/her motor behavior, considering the external context: physical and social environment associated with the internal context (characteristic of the organism), in time and space.

The caregivers hardly practiced and frequently rejected the use of walkers, demonstrating their possible access to information on the negative effects of its use. Chagas et al. (14) investigated the beliefs of 26 
parents in the state capital of Minas Gerais about the use of walkers, divided in two groups: those who put and those who did not put their children in the equipment. According to the authors, the pediatricians' opinion, highlighting the walker's possible negative effects, influenced the parents in the group who did not put their children in the walker. Biasoli-Alves et al. (29) affirm that mothers as from the 1980's present attitudes and beliefs based on the scientific search for orientation, resting on books, magazine articles or advice from pediatricians and psychologists.

Nevertheless, in some cases, the walker was more practiced than considered important. In the study by Chagas et al. (14), the group of parents who chose the walker were also aware of the pediatrician's contraindication of the equipment, but other factors influenced their decision.

Agreement was observed between the practices and the importance attributed in $73 \%$ of the items. Nevertheless, for nine activities, a statistically significant difference was found between practice and belief. Beltrão (30) looked for convergences and differences in the beliefs, socialization targets and parental care practices in two ecological contexts in the Amazon, urban and non-urban, and also found divergence between some practices and beliefs. The author concluded that strategies the mothers use change faster at the intellectual than at the action level.

In addition, the contrast between some practices and beliefs may be due to the complex production of the parental beliefs, as these derive from the individuals' experiences as parents as well as from the cultural experience accumulated for generations about what it means to be a parent and how to act in these roles $(4,14)$.

One limitation in this study was the use of a retrospective questionnaire, in which the memory bias may be present. Nevertheless, we tried to minimize this effect by selecting children closer to the period of interest for this study. Another aspect is the small convenience sample, with very homogeneous characteristics, making the item calibration less stable. For future studies, larger samples are recommended with random distribution, in order to verify whether the parenting practices and beliefs differ according to Brazilian caregivers with different sociodemographic profiles. Based on the results of these studies, intervention plans can be elaborated in the field of motor development, targeting the parents, in view of their own beliefs and practices.

\section{Conclusion}

In this study, it was verified that the participants in this study, caregivers of children who attended an aquatic stimulation program and had higher socioeconomic level, presented practices focused on their children's motor development, such as family interaction through games, offering of toys, lap time and space for free movement. Most practices were based on parental beliefs but, for some activities, the beliefs and practices diverged, reflecting the complexity inherent in the establishment of parental beliefs.

\section{Acknowledgements}

The authors are grateful to the Project "Nada Melhor" and the Brazilian Scientific and Technological Development Commission (CNPq) for the grant.

\section{References}

1. Engle PL, Black MM. The effect of poverty on child development and educational outcomes. Ann N Y Acad Sci. 2008;1136:243-56.

2. Bornstein MH, Tamis-lemonda CS. Parent-infant interaction In: Bremner JG, Wachs TD. Blackwell Handbook of Infant Development. Malden, MA: Blackwell Publishing; 2010. p. 458-82.

3. Guralnick MJ. Family influences on early development: integrating the science of normative development, risk and disability, and Intervention In: McCartney K, Phillips D. Blackwell Handbook of Early Childhood Development. Malden, MA: Blackwell Publishing; 2006. p. 44-61.

4. Bornstein MH. Cultural approaches to parenting. Parent Sci Pract.2012;12(2-3):212-21.

5. Harkness S, Super C.M. Introduction. In S Harkness, CM Super. Parent's cultural belief systems: their origins, expressions, and consequences. New York and London: The Guilford Press; 1996. p.1-23.

6. Macarini SM, Martins GDF, Minetto MFJ, Vieira ML. Práticas parentais: uma revisão da literatura brasileira. Arq Bras Psicol. 2010;62(1):119-34. 
7. Scola C, Bourjade M, Jover M. Social interaction is associated with changes in infants motor activity. Socioaffect Neurosci Psychol. 2015;5:28256.

8. Serdarevic F, van Batenburg-Eddes T, Mous SE, White T, Hofman A, Jaddoe VW, et al. Relation of infant motor development white nonverbal intelligence, language, comprehension and neuropsychological functioning in childhood: a population-based study. Dev Sci. 2016;19(5):790-802.

9. Stapel JC, Hunnius S, Meyer M, Bekkering H. Motor system contribution to action prediction: Temporal accuracy depends on motor experience. Cognition. 2016;148:71-8.

10. Defilipo EC, Frônio JS, Teixeira MTB, Leite ICG, Bastos RR, Vieira MT, et al. Oportunidades do ambiente domiciliar para o desenvolvimento motor. Rev Saúde Pública. 2012;46(4):633-41.

11. Freitas TCB, Gabbard C, Caçola P, Montebelo IML, Santos DCC. Family socioeconomic status and the provision of motor affordances in the home. Bras J Phys Ther. 2013;17(4): 319-27.

12. Soares ES, Flores FS, Katzer JI, Valentini NC, Corazza ST, Copetti F. Análise das oportunidades de estimulação motora em ambientes domiciliares na região central do Rio Grande do Sul. Rev Bras Educ Fis Esporte. $2015 ; 29(2): 279-88$.

13. Silva PL, Santos DCC, Gonçalves VMG. Influência de práticas maternas no desenvolvimento motor de lactentes do $6^{\circ}$ ao $12^{\circ}$ meses de vida. Rev Bras Fisioter. 2006;10(2):225-31.

14. Chagas PSC, Mancini MC, Tirado MGA, Megale L, Sampaio RF. Crenças sobre o uso do andador infantil. Rev Bras Fisioter. 2011;15(4):303-9.

15. Unalan H, Tuna F, Kokino S. Quality of life of primary caregivers of children with cerebral palsy: a controlled study with Short Form-36 questionnaire. Dev Med Child Neurol. 2004;46(9):647-8.
16. Associação Brasileira de Empresas de Pesquisa (ABEP). Critério de classificação econômica Brasil. CCEB-ABAP-redes. 2015 [cited 2015 May 26]. Available from: https://tinyurl.com/hb77zc7

17. Karasik LB, Tamis-LeMonda CS, Adolph KE, Bornstein MH. Places and postures: A cross-cultural comparison of sitting in 5-month-olds. J Cross Cult Psycol. 2015;46(8):1023-38.

18. Lobo MA, Galloway JC. Enhanced handling and positioning in early infancy advances development throughout the first year. Child Dev. 2012;83(4):1290-302.

19. Linacre JM, Wright BD. A user's guide to bigsteps: Rasch-model computer Program. Chicago: MESA Press; 1993.

20. Bond TG, Fox CM. Applying the Rasch model: Fundamental measurement in the human sciences. 2nd ed. New York: Routledge; 2010.

21. Wright BD, Stone MH. Best test design. Chicago: MESA Press; 1979.

22. Mancini MC, Fiúza PM, Rebelo JM, Magalhães LC, Coelho ZAC, Paixão ML, et al. Comparação do desempenho de atividades funcionais em crianças com desenvolvimento normal e crianças com paralisia cerebral. Arq Neuro-Psiquiatr. 2002;60(2B):446-52.

23. Basilio ML, Faria-Fortini I, Magalhães LC, Assumpção FSN, Carvalho AS, Teixeira-Salmela. Cross-cultural validity of the Brazilian version of the abilhand questionnaire for chronic stroke individuals, based on rasched analysis. J Rehabil Med. 2016;48(1):6-13.

24. Duncan GJ, Gibson-Davis CM. Connecting child care quality to child outcomes: drawing policy lessons from nonexperimental data. Eval Rev. 2006;30(5):611-30.

25. Kobarg APR, Vieira ML. Crenças e práticas de mães sobre o desenvolvimento infantil nos contextos rural e urbano. Psicol Reflex Crit. 2008;21(3):401-8.

26. Martins GDF, Vieira ML, Seidl-de-Moura ML, Macarini SM. Influência do apoio social sobre crenças e práticas maternas em capitais e pequenas cidades brasileiras. Psicol Refl Crit. 2011;24(4):692-701. 
27. Gontijo APB, Magalhães LC, Guerra MQ. Assessing gross motor development of Brazilian infants. Pediatr Phys Ther. 2014;26(1):48-55.

28. Bezerra IFD, Torres VB, Lopes JM, Baroni MP, Pereira AS. Influência do uso da rede de descanso no desempenho motor de lactentes nascidos a termo. Rev Bras Crescimento Desenvolv Hum. 2014;24(1):106-11.

29. Biasoli-Alves ZMM, Caldana RHL, Silva MHGFD. Praticas de educação da criança na família: a emergência do saber técnico-científico. Rev Bras Crescimento Desenvolv Hum. 1997;7(1):49-62.
30. Beltrão MCM. Convergências e divergências no sistema de crenças e práticas parentais: Comparação de duas amostras amazônicas [dissertation]. Belém: Universidade Federal do Pará; 2013. p. 1-161.

Received in $01 / 05 / 2016$

Recebido em 01/05/2016

Approved in 02/07/2017

Aprovado em 07/02/2017 